She Embodies: A Materialized Collective 34

\title{
She Embodied: A Materialized Collective
}

The Collective

Asia Amos, asia.amos@memphis.edu Counseling Psychology, University of Memphis

Keishana Barnes, keishana.barnes@memphis.edu Educational Psychology and Research, University of Memphis

Tharwa Bilbeisi, fblbisi@memphis.edu Communication, University of Memphis JoAnna Boudreaux, Jbdreaux@memphis.edu Communication, University of Memphis Emily El-Oqlah, emilyeloqlah@gmail.com Counseling Psychology, University of Memphis Noor Ghazal Aswad, noorghazal87@hotmail.com Communication, University of Memphis Dorothy'e Gott, dhgott@memphis.edu Counseling Psychology, University of Memphis Rachel Hamilton, hmlton6@memphis.edu Educational Psychology and Research, University of Memphis Tracy Hernandez, tnmcneal@memphis.edu Instruction and Curriculum Leadership, University of Memphis

Clarie Koehn, cjkoehn@memphis.edu Counseling Psychology, University of Memphis Susan Naomi Nordstrom, snnrdstr@memphis.edu Educational Psychology and Research, University of Memphis

Aailyah Shivers, aaliyah.shivers@gmail.com Anthropology, University of Memphis Tiffinie Snowden, tbsnwden@memphis.edu Anthropology, University of Memphis Hannah Tabrizi, Hannah.Tabrizi@memphis.edu Communication, University of Memphis

\footnotetext{
Abstract

This collaboratively written piece materializes the collective experiences of 14 students and an instructor in a graduate-level feminist research methods class in the United States. Instead of writing a traditional seminar paper, the class decided to continue our weekly discussions, during which we wrestled with both theory and practice, in text in a final paper. It just seemed like the best way to end our time together. In so doing, the she embodied collective furthers feminist writing practices that embrace uneasy collectives of varying viewpoints. This particular collective acknowledges our she, but recognizes, listens to, and celebrates all the powerful pronouns that create a collective. The collective offers a brief introduction and lengthy appendix to situate the piece. We do not adhere to a singular
} 
feminism in the piece. Consequently, our collective is a way of doing unity differently, of attending to and residing with the frictional thought within feminisms and finding that frictional thought as generative. We invite readers to join our collective, to think together across differences without reducing those differences to similarities.

Keywords: Feminist Pedagogy, Collaborative Writing, Collectives

\section{Introduction}

The karmic female spirit lives on among women across the globe. She is reborn among the colorful faces and shapes of the femme. She is a constant voice that transmigrates throughout the eons of time; she has always been and always will be. SHE is SHE-returning to the physical realm anew. She completes the karmic cycle again and again, her mission to bring forth life, educating as she is learning; carrying on her back the load of her labors as she navigates the muddied terrain. Like a starfish, She moves through the ages reforming lost limbs as She adapts to the ever changing demands on her femininity. Her movements fluid, she traverses time and space; in borderlands She finds home. She is Black, She is Brown, She is White, She is spotted, She is aromatic, large-boned, petite, curvy, flat, red, yellow and creamy. She is hard and She is soft. She is nature and She is nurture, resilient and strong, She is scrappy and resourceful. She is imperfect, yet She is complete. She is not one, but all. And when She unites, she is power.

The students of the University of Memphis's Feminist Research Methods class came together to create power, a moving experience of creative enterprise. Unorthodox in our innovative venture, the women or She's of the collaborative experiment joined together to push back against institutional hegemonic prominence. Her work as She, voicing a multiplicity of identities, is inherently resistant and revolutionary. Our mission, led by a trailblazing anchor, is to collectively share in the feminist experience of life, struggle, and the search for home. Home-grown. Home-made. Home-spun. She, We, search for a space, a dwelling, a habitat to offer, nay, bestow our creation. Our poetic words, artistic expressions, our handiwork is rendered from the depths of our beings. We believe these creations-these voices, voyaged a journey beyond ourselves, an amalgamation of rebirthed words spoken by our mothers and theirs before them. The collective voices joining to become one, individual and united in their message to resist and reform. The following is our progeny--

\section{She Embodied}

This course has been an example of what education could be (should be?). Did we become a "happening?" Did we become "greater than the sum of our parts?" (Tsing, p. 23). Anticipation for the course. Feminist. Research. Methods. Finally. Our teacher asked us what we wanted to learn about ( $\mathrm{hmmm}$... what did we want to learn about?). She worked and responded. Our disciplinary identities of psychology, anthropology, communication, and education...disciplined-based understandings with the 
individual histories, theories, and methods/methodologies. Unpacking these areas and how ideas manifest in our disciplines...helping us to form a more informed critique. We examined what motivated us...why are we here?? Unsure of certain labels at times...should I even be in this class?? Am I this kind of feminist? Queerness? Self-discovery. Sharing as valid research. Different ages. Different places in life. Different careers and goals. Different family scenarios. Different religions and ethnicities... "There's never this many Muslims in a class!" Making adjustments as needed...not sticking to the syllabus "just because." Flexibility. Safe space for risk taking...admitting when we "don't know" or have "messed up." Rearranging seats to form a type of circle (without asking) so we can better engage with each other. There was cooperation. We found real life examples and things happening and asked how can we learn from this? How can we help? We critically examined ourselves...how are we perpetuating racism, sexism, all the -isms? How do we benefit? Learning from each other. No egos. Profanity because there are horrible things happening and we don't have time for "politeness" and "respectability." Imaginary sign reminding us of the "reason." Laughter. Lots of laughter. Texting... where are you? Class is starting. Change of plans for Pride. We missed you in class! No, you are gonna graduate. Are you ok? I noticed you were quiet today. Oh, you have kids too? How old are yours? We can go to the museum together. Have you eaten today? I brought snacks. Giving rides and walking back across campus together. Safety.

If feminist theory posits that if women are taken care of, all things will be taken care of...then, if all courses were taught, planned, and run like this feminist methods course, might all our higher education issues be solved? Is this not the way to engage with and change educational spaces for the better? Is it possible to come together to think differently about gender, race, sexuality, religion, dis/ability, everything? This paper is a result of self-processing, both in-class and outside of class. Our process was not always smooth but felt natural. We present this collective to the reader as a way of considering writing and thinking differently. It is indeed something to sit and think with. We believe we need more explorations of what it means to think differently as a collective. "Thinking with" is provoking - a way to extend our conversation. We invite. You to think with us. Join our collective. Extend the conversation. This is where the work is.

hello you.

again

i thought i had lost you.

somewhere

in the time and space between dreams

yet here

you

are

always existing in some dimension

separate from where i thought you were

moving through a space that was never made for you

never made for us

Reconceptualizing Educational Research Methodology 2020, 11(2) https://journals.oslomet.no/index.php/rerm 


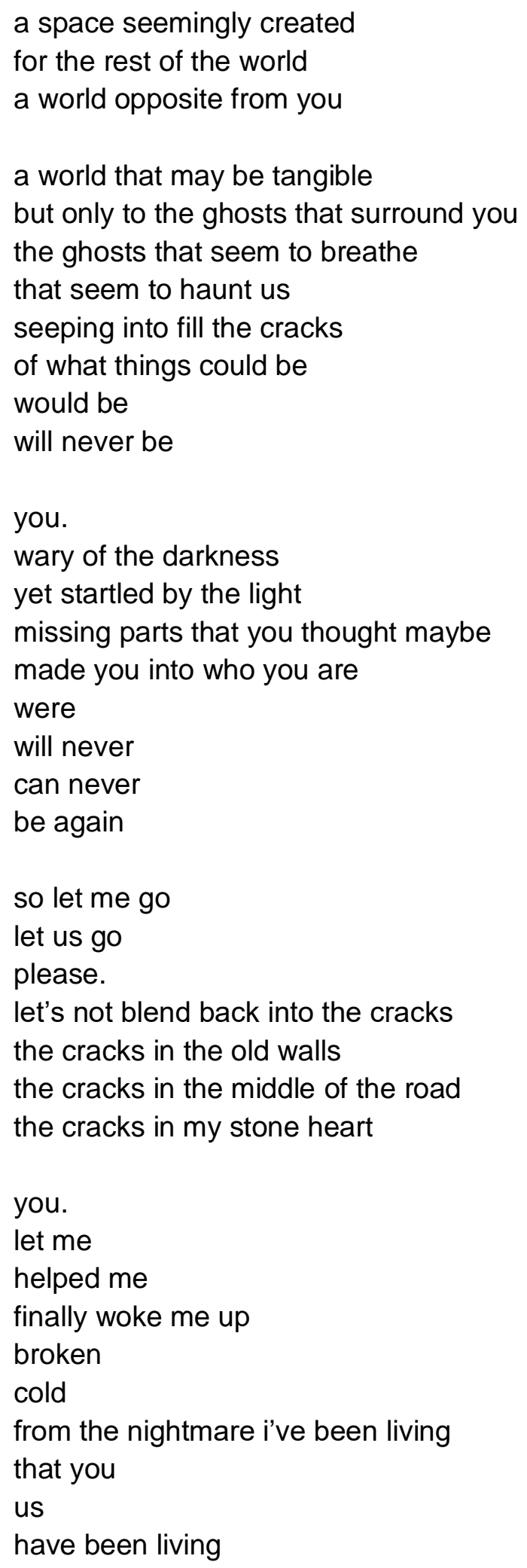


to see

that the monster can be sent back

to the ivory tower that now crumbles

broken and laid bare

to feel what you

us

have felt for so long

too long

so let's move together

now hopeful

yell our battle cries into the stars

lay together and drown in the flowers that surround us

reborn

renewed

redone

hello you.

thriving outside of ivory towers

mobilizing against misogyny

determined to change the narrative

not to be compared

unlike what you thought

dominant yet soft

intersectional and always shifting

hopeful and inclusive

Black and bold

a powerful force

from the seed of hip-hop culture

supportive of masculinity

comfortable with sexuality

relies on self-defining respectability

reflects a liberated activist 
not to be policed by patriarchy

attracts and delivers comfort

slays traditional standards of beauty

Searching, dreaming, fear

Years of love have brought me near

My journey to here

Reclaiming

the Space that is ours

Forgetting

the Fragility of being alone

In this rose-colored existence

I am enchanted at the world's wondrousness

Yet, the flesh is tender to the touch

Thoughts linger long

The Syrian is a refugee

She has left the watan, the Land of Jasmine and Pistachio

The Land of Honking Taxis, and Salted Butter Corn on the Street

Cracked shells, Broken Windows, and Sarin Gas, drove her out.

She sits on the curb, staring at the stars

She Longs. For. Home

Staring at the stars, I am wondrous again

Memories of wrought iron balusters on an Aleppan veranda with a minty breeze

Where nana drinks hot chai with sugar cubes

Basking in her Warmth, in the Togetherness, in the Belongingness 
of that Transient Immortal Place.

Oh scrolls, write down this prayer

Take me back, to the Land of Citadels, to Halab, to that Moat

But let me sit by the curb with those that yearn too.
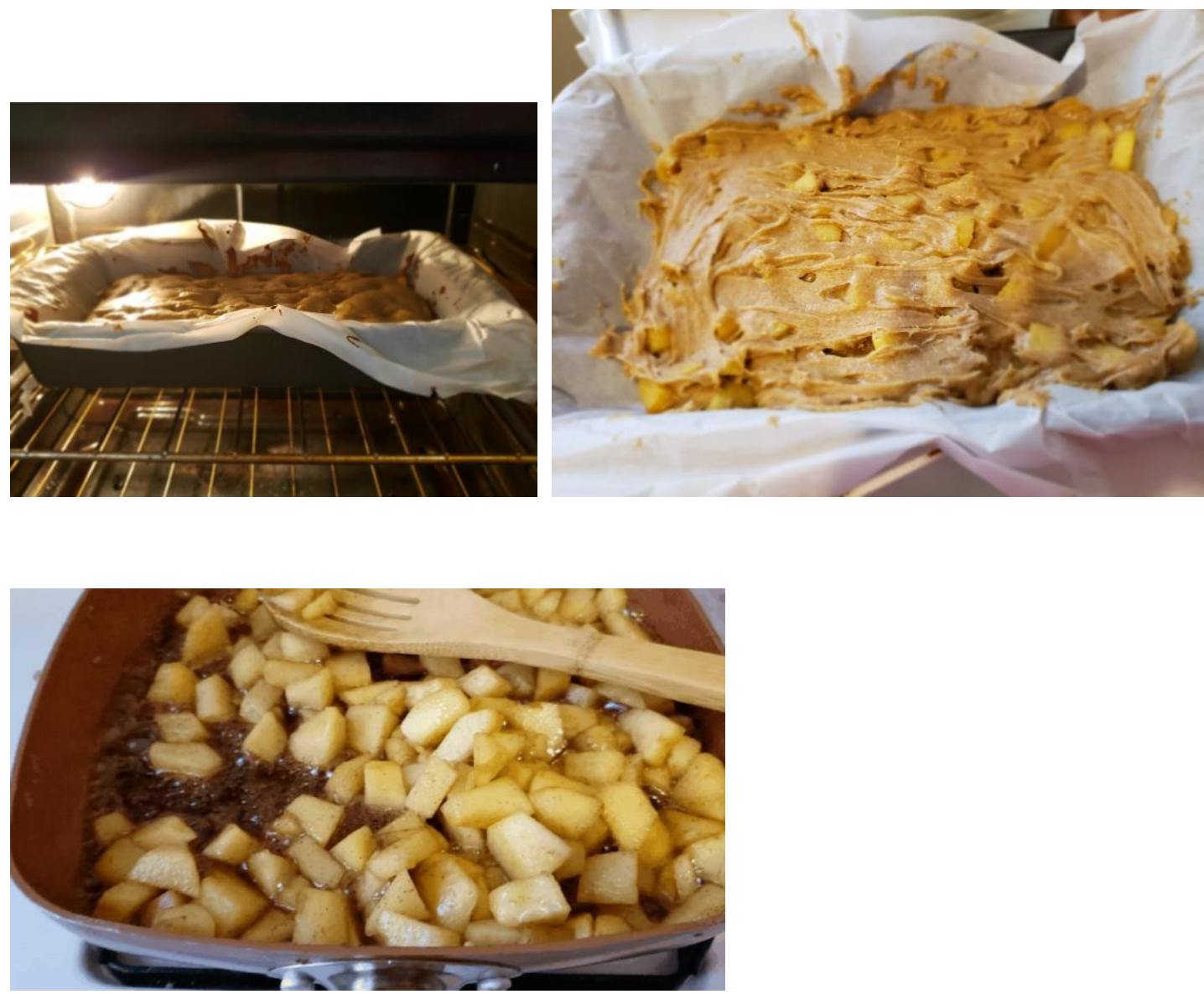

Hyphenated

What is life like at the border, on the hyphen?

\section{Arab-American}

Bi-racial

Al-Zoubi 
Al-Fatiha

The opening

My experience in this class has been an opening of sorts.

My first time in a class with other Muslim women, with other Arab women.

My first time in a class where Palestine is in the reading.

Maybe life has been hyphenated until now?

I have spent my life as the other and another

The stranger and the neighbor

The virgin and the whore

The child and the caretaker

I have been both old and young

Big and small

Consecrated and desecrated

Unattainable and too easily attained

My body has paid the price

It's been rented, leased, and sold

And if my body is my home, I have no home

For my body is inhabited by others, or so I am told 


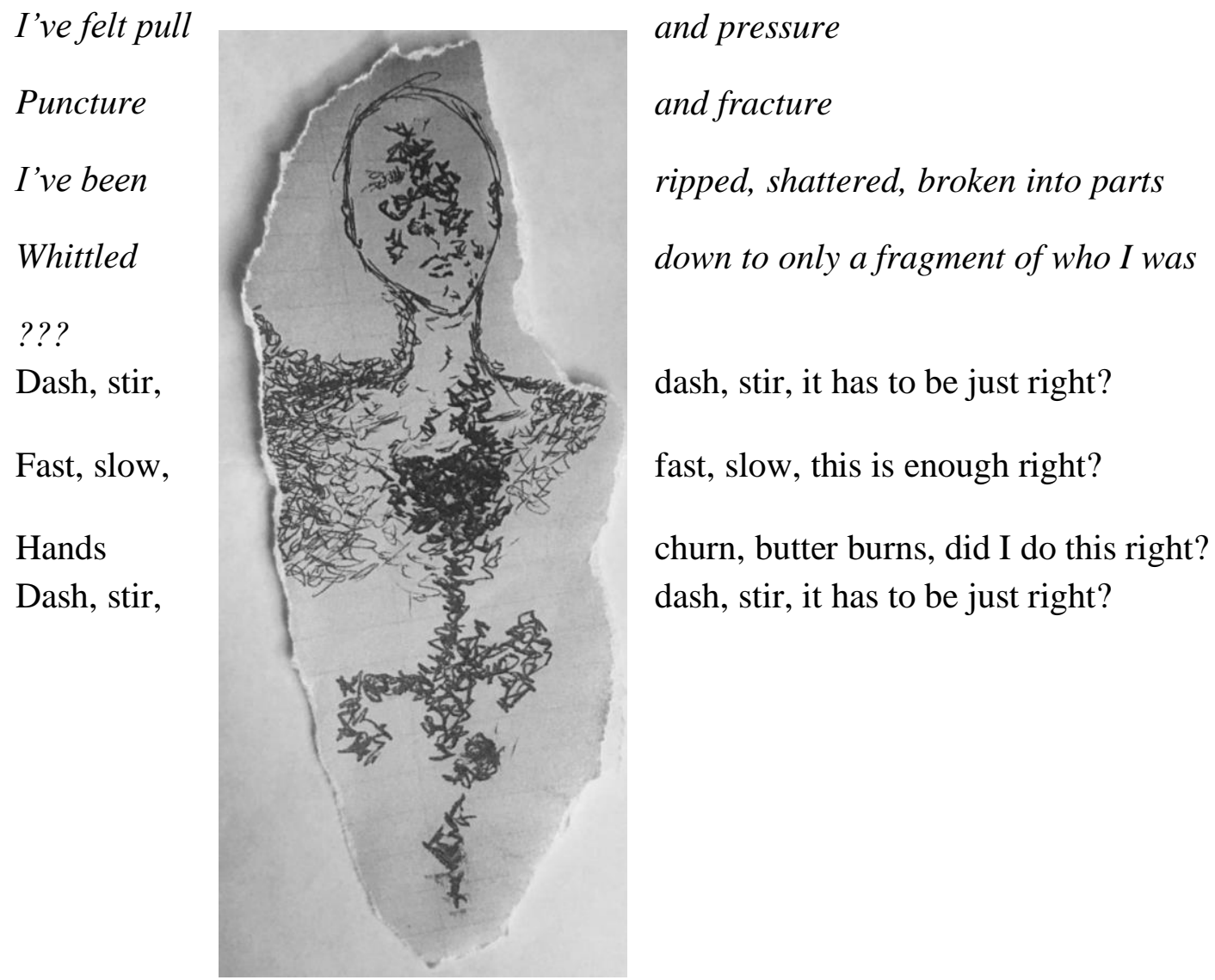

what are you?

are you black or white?

mutt

half-breed

Chink

\section{Maternalities}

my mother

small, dark, boiling, woman

from pattaya, thailand

who writes journals of illustrated stories

in thai

สมุดบันทึกเรื่องราวภาพประกอบ

the clerk looks down at my small hand as I fumble with the pen 
"my mother is illiterate"

I watched her grab a woman by her hair

for calling her the $n$ word

and shake her head back and forth, back and forth, back and forth

like a chicken

my mother's lips were folded together

and this noise came from her throat

$\mathrm{mmm} \mathrm{mmm} \mathrm{mmm}$

as she slapped, slapped, slapped

that woman's face

my mother's mother

from singapore

who left my mother when she was a baby

one night my mother asks my opinion on the matter

she is sitting in the dark, smoking a cigarette

tears stream down her face

boiling tears

maybe I was 7 or 8 or 10

"what kind of mother leaves her baby?"

and my mother's chinese grandmother

the mother of her father

who sent my mother out of the house

at age 12

and my father's mother

white, cherokee, "blackfoot indian"

married, widowed

widowed again

married again

beaten with a belt

and a frying pan

who raised one son and seven daughters

one son, my father

who grew up and went to thailand

and sent his mother his entire air force stipend

because she couldn't stand up for herself

not allowed 


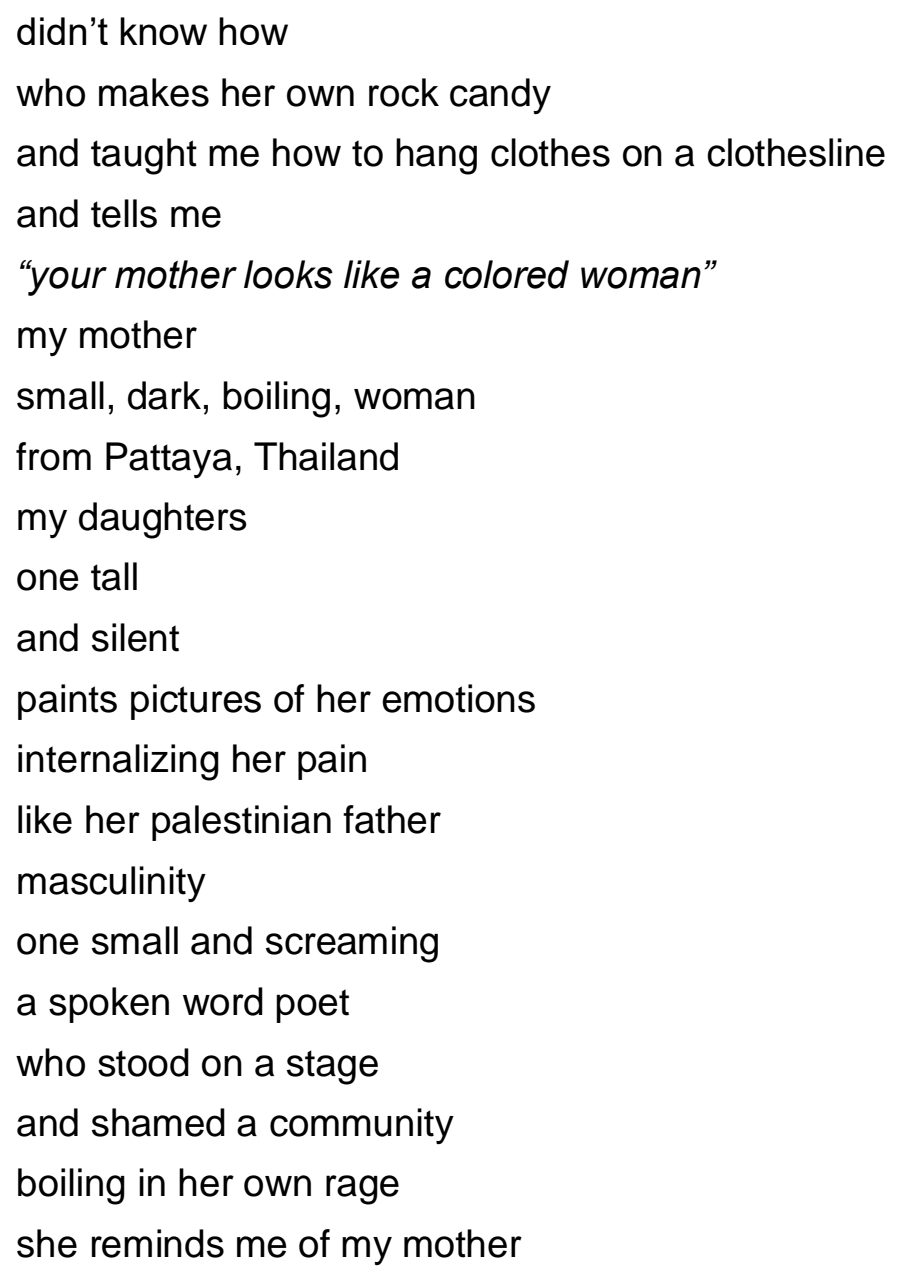


I've reexamined past, present, and future

To reproduce myself as a patchwork thing

And now I wear my patches with pride

As a badge of honor, a middle finger

I am not parts of self

But a self of parts

Still, the scars from the stitches remain

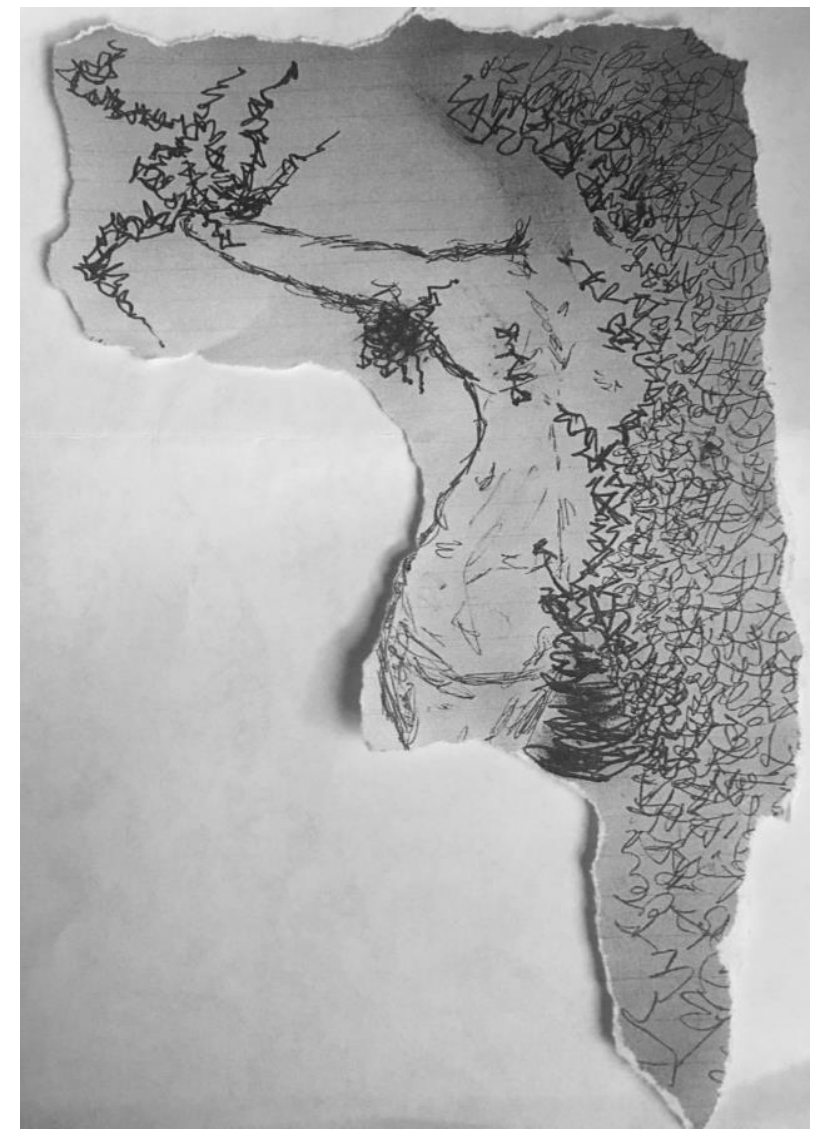

\section{Confusion}

"One ever feels his (her) twoness, -- an American, a Negro; two souls, two thoughts, two

I'm a Barbie girl in a Barbie world unreconciled strivings

Girl, put your records on, tell me your favorite song

Life in plastic, it's fantastic

I hope you get your dreams

You can brush my hair

Don't you let those other boys fool you

Gotta love that Afro hairdo

Imagination, life is your creation

When you gonna realize that you don't even have to try any longer?

Tryna fix myself for society

Do what you want to

Tryna mix myself for society

Just go ahead, let your hair down

But can you tell me, where is love in anxiety?

Can you tell me, where is love in anxiety?

You're gonna find yourself somewhere, somehow

Reconceptualizing Educational Research Methodology 2020, 11(2) https://journals.oslomet.no/index.php/rerm 
She Embodies: A Materialized Collective 46

Brown skin, you know I love your brown skin

I like my negro nose with Jackson Five nostrils

With my deep brown eyes...I stand alone

Where are your people from? Maybe Mississippi or an Island

White girl wanna touch it

I told her please don't touch me

Did you think this was a petting zoo?

Apparently your skin has been kissed by the sun

\title{
I am not this skin
}

I can't tell where yours begins, I can't tell where mine ends

\section{I am not my hair}

Don't touch my hair

When it's the feelings I wear

\section{I am the soul that lives within}

Don't touch my soul

When it's the rhythm I know

This here is mine

Sit down!

\section{Righteous Indignation}

\author{
Appreciates women's emotional flexibility \\ The truth will set you free \\ Say it Loud, I'm Black and I'm Proud \\ But first, it'll piss you off \\ Who the fuck do you think I is? \\ Tell the storm I'm new \\ Yo operator, or innovator \\ Motivate your ass call me Malcom X \\ I'ma riot, \\ Fuck you hater, you can't recreate her no \\ 'Cause I need freedom, too \\ And you can't find the fighter \\ I break chains all by myself \\ It ain't my fault that I'm out here getting' loose \\ I'ma keep running \\ Blame it on my juice \\ Won't let my freedom rot in hell \\ I'll rise up \\ And move mountains \\ 'Cause a winner don't quit on themselves
}


This world is new to me, I do not know it

\section{Lost}

Loves struggle

When I left I thoug43443ht I would be stronger

But in fact, it took away my energy

I try to cover up what I feel inside

Hard to tell you that I could not really see

Can you focus on me?

Strumming my pain with his fingers

Can you focus on me?

Singing my life with his words

Can you focus on me?

Killing me softly with his song

Telling my whole life with his words

Lately I've been a little fed up

Killing me softly with his song

But I don't wanna give up

Killing me softly with his song

Can you focus on me?

\section{Faithful}

Loves the Spirit

Her shroud is loneliness, her God was listening. Her heaven would be a love without betrayal.

In the corners of mind

I just can't seem to find a reason to believe

That I can break free

There is no pain, Jesus can't feel

Cause you see I have been down for so long

Feel like the hope is gone

There is no hurt, that He can't heal

But as I lift my hands, I understand

For all things work

That I should praise you through my circumstance

According to his Holy will

Take the shackles off my feet so I can dance

I just want to praise you

You broke the chains now I can lift my hands

\section{Found?}

Loves music. Loves dance.. Loves the Folk. Loves herself. Regardless

Don't You know that I've been looking for You?

Never felt, never held, never had no love like you 
I realized nothing else will satisfy me

But this right here

I did not know it was love

Now that I'm changed

Everybody, everybody wants to know

Where you're goin' to, 'cause they wanna come

Or so they think until they find the cost of it

'Til they find out, find out what you lost for it

No one can keep me away from You

And l'd do it all again

'Cause I found love

[And] When it feels this good you better keep it

I can't resist this sweet surrender

Because in exchange you give me peace of mind

\section{Willful}

\section{Game into this world}

Wanting to know more and in greater depth than is considered "good" for one

\section{Daddy's little girl}

\section{And daddy made a soldier out of me...}

And you think of roses and daisies

And I think of passion and fire like Hades

\section{Tough girl is what I had to be}

You say all the time, peace and quiet

I need a riot

He said, "Take care of your mother"

My daddy said shoot

I'm guarding my gates

Watch her go wild

Missy in this bitch

Found her confidence

doin'shit you ain't never seen

So she a pro now

Don't test my mouth

$$
\text { They say the glory's all mine }
$$

Thought I couldn't breathe without you, I'm inhaling

They say the truth is my sound 


\section{Lost at sea}

All this time I have been walking backwards into cold, salty waters, never able to predict when or how large the next wave would hit me, or which one would take me to drown at the bottom of blue emptiness. In these moments, between warring with an uncompromising, proverbial Poseidon, I find myself lost at sea. Will I go down fighting, fists clenched and screaming at a world that has always wanted to watch me fade to foam and debris? Will I be remembered as an angry siren or elusive sea witch that sought to lure man to its end? How will those who loved me tell my tale? Is it one of a feisty sailor who braved an unstoppable storm? Or will they draw from uncomfortable silence, unwilling to succumb to the same fate as mine?

I wonder to myself, quiet, meek, and beaten down, how long have the tides weathered me? To what extent? In all of my trials and tribulations, I have fought against an untouchable force, one that is invisible yet tangible. Years of battle have turned me into a shapeshifter. I have changed form. Yet this has been no metamorphosis. I'm no butterfly, beautified through a single struggle to escape one's cocooned coffin. From boulder to stone to pebble. From joy to sadness to broken. A gain through loss, from a chipping away piece by piece until all that is left is a grain of sand.

I look to the coast and gaze upon a tall, ivory tower. It's a tower that stands on many grains of sand, its foundation only made possible through those that lay broken-down beneath it. I was once promised a beacon of light to show me through the darkness. But this is no lighthouse, for it does not promise a warm, illuminating glow. I was sold a home away from home with a family I cannot break bread with. Those that reside inside the tower's walls want it to remain a dark, hopeless space. Yet I want to remain hopeful. I want to believe all the lies that are built within the walls. For when the walls whisper, we who wade the waters are told things will change.

"Have faith."

"We will have a home one day very soon."

"It's bad, but, for now, just float in the sea." 
But when lost at sea, where does one find home?

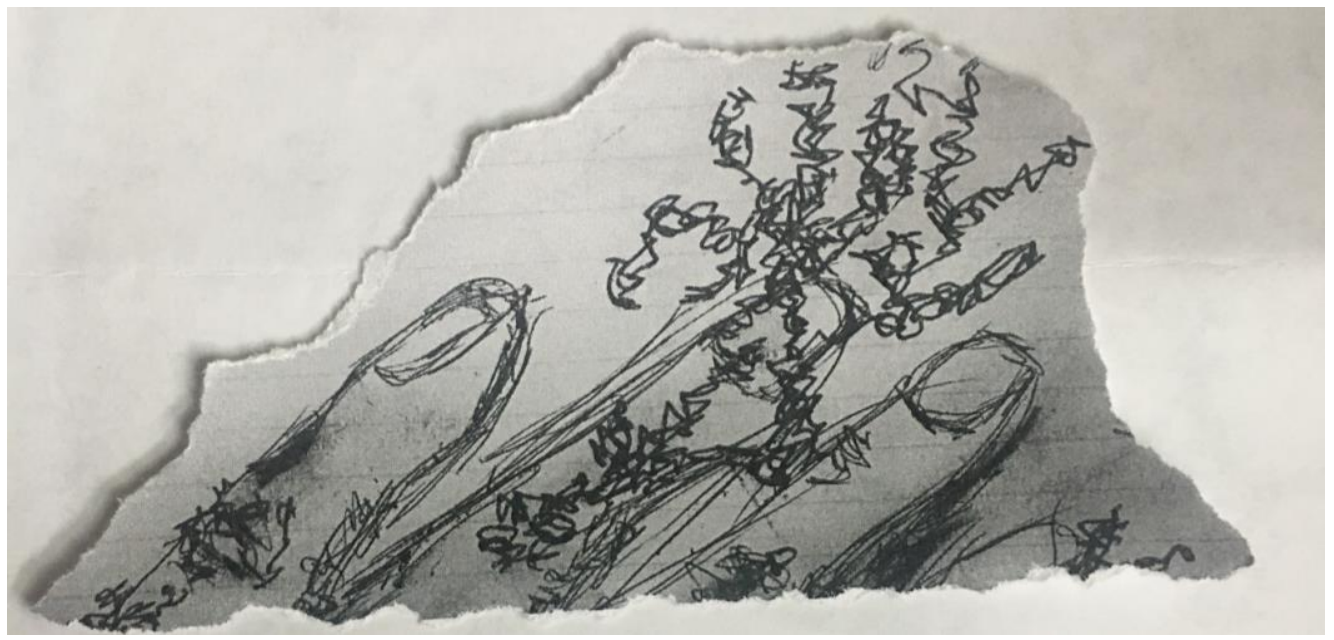

Aimed, Willful Intent

Planned Predetermined

Purposeful knowing

Guarded, locked and loaded

Equipped with Microsoft word and google docs

Filled to the core with citations affirming positions of power where the very forms discussing this thing called feminism - serve as the gatekeepers.

Permeating literature with scholarly material

With skewed viewpoints

Not recognizing our own role in this misalignment of power

Privileged voices discussing the framework for which the disenfranchised will be made to conform to or rebel against

We stand.

Guarding the ivory tower we believe we should critique

Validating words of those who have access to the spaces we hold near and dear

Torn.

Ripped between the realities of living life but wanting to make it better

Expanding that small sliver of hope to be a gapping hole of radical change because for some it's life or death... 
Or does it just sound good;

The sound of your keyboard typing about inequities

The sound of your voice on the megaphone at a march blanketing statements for ALL WOMEN The sound of the printer, translating ink to paper to as you type out your theories

The sound of the affirming claps and snaps as others champion YOU as a warrior

As being someone who cares enough to

Publicly pronounce points of privilege using your platform

Hop on board the triggering train.

Tantalizing talks serve to teach

But who stands to be the person who is taught?

How does one reality triumph those who have been historically and continuously silenced?

Do your publications make you an expert on my realities?

Does your analysis serve to make the change necessary to create a victory that is worth risking blood, sweat, tears and fears over?

Are we just hostages?

Created by the institution we continue to dwell in

And hope to do WELL in

Confined to the lines of which radical affiliations and frameworks are permitted as long as this phantasmic idea of change stays within the parameters of upholding this eggshell colored building

Who gets to have a seat at the table with a MEGAphone and a pot full of cash?

Who gets to make equitable changes?

Who gets to include the lives at stake?

Who gets to take part in the making of their own history?

Must we stand as intermediary sponges constantly absorbing the faults of society while the major players whine and dine at the cost of our physical, mental, financial and emotional labor?

Is it possible to alleviate the massive disparities of this fantasy or idealistic premonition of the future?

We must make change equitable and equally meaningful in all spaces without assimilating to the cream colored fortress

Knowing that our position doesn't provide more to the movement, then those who never dared

Never cared 
Never could

Never would

Get the credentials in which we seek.

Disillusion ourselves with a new idea where it's not a matter of who gets to have a seat at the table but the factors in which this table is allowed to exist that is central to the problems we face

Have we lost sight of the cause?

Shall we just pause...

Reflexively reflecting on where we really stand in the grand scheme of things.

Allocating financial power to the same institution keeping change makers out to protect this fragile egotistical institution.

The same institution continuously oppressing women in vicarious ways using small tokens of appreciation and commemoration as a tool to keep us semi-satisfied and

Oddly quiet.

So that we--

continue to feed it.

Straddling the medians of riding for revolutionary changes and funneling funds to those in power who profit from our gestures

Riding this wave of bandwagon activism

To them-it's about marketing

It's about competing in a market where buzzwords like "diversity" "inclusion" "equitable" "equal" fuel trends for companies to hunt for talents which align with their strategic goals

Giving us hope that we can be a part of the change we seek

As we make our rounds through this cycle of trauma

Again

And again

....and again.

Make no mistake

The degrees before or after your name makes you no more valuable than any one else doing this work

Your ability to exist and have a voice of impact in spaces where feminist ideas are problematized and scrutinized-hold no greater weight than those feminists who rally in the streets, who organizes and strategizes in closed meetings minus hackable, buggable and traceable technology, who stirs up the pot risking life-not livelihood, to get their point across.

Yet we stand. 
She Embodies: A Materialized Collective 53

Guarded, locked and loaded

Ready....

\section{Appendix}

Dear Readers,

A collective she, a solidarity of difference, wrote this article. Rather than write a traditional graduate seminar paper, the she offered that we write together, something about our experiences in the class, Feminist Research Methods. We are unsure as to who suggested it or how it came to be. It just did and we all agreed that a collaboratively written piece would best reflect our experiences as a class. What better way to carry on the rich tradition of feminist scholarship that has disrupted so many existing practices? Surely, disrupting the traditional seminar paper into a collaboratively written piece would contribute to this tradition. In particular we aim to contribute to the practices of other feminist scholars writing together (Doane \& Hodges, 1995; Handforth \& Taylor, 2015; Harde, 2013). This piece, we hope suggests that 14 people can come together in a class, in a piece of writing, and how those 14 people can create an uneasy solidarity that is always in practice and grounded in listening to differences. We use the term "people" instead of feminists in this endnote to reflect our experiences with the term "feminism." We recognize the term's history and who it has welcomed and who it has excluded. We exist within its fraught and multiple definitions. We offer this endnote to situate our practices.

Much like Wyatt \& Gale's (2018) idea of writing to it, a process of writing toward something on a plane of immanence, we began with a simple question. What is your feminism? We knew that somehow the piece would come together, much like our class discussions in which varying viewpoints about the readings would somehow coalesce into new and different understandings. Somehow 14 people would come together to create something, we just had no idea what that something would be. With a handful of remaining weeks in the semester, we dedicated class time to writing together. Initially, we worked on our individual contributions away from class as we figured 14 people attempting to write together in situ would be difficult. Moreover, we sought to maintain individuals within the collective. We then listened to each other as we read our pieces. Following that, we identified connective lines between the pieces that we then merged on a Google doc. We use varied fonts, photographs, and art in the printed version so as to materialize how our voices come together in an ever-shifting she, a materialized collective.

The remaining writing sessions followed a predictable format. Each writing session began with showing the google doc on the classroom screen and a reading of the piece so that we could experience how the piece was reading that day. In addition, we wanted to hear each person read her contribution to hear how our voices mixed into the she that day. We then set to work, sometimes collectively other times in small groups, on the piece. We ended the session with another read aloud of the piece, each feminist voicing her she into the collective. Our last class, which took place at our professor's home, ended with us reading aloud the piece together. 
We do acknowledge the potentially problematic idea of using the term "she." However, prior to the semester beginning, the instructor sent an email asked for our preferred pronouns and each of us said "she, her, hers." This particular collective acknowledges our she, but recognizes, listens to, and celebrates all the powerful pronouns that create a collective.

The email that she sent served another purpose. Recognizing that the class consisted of students from a variety of disciplines and individual experiences with feminisms (some wonderful and enlightening, others less so), she asked the students which areas of feminism they wanted to cover. For, if feminist research is about disrupting the supposed binary of theory/practice, then each feminist methodological approach is different. She then created a rigorous reading list of contemporary feminist work that reflected student interests. These texts included: Ahmed's (2017), Living a Feminist Life; Boyd \& Ramirez (2012) Bodies of Evidence: The Practice of Queer Oral History; Nash's (2019) Black Feminism Reimagined after Intersectionality; Smith, Tuck, \& Yang (2019) Indigenous and Decolonizing Studies in Education; Tsing (2015) The Mushroom at the End of the World: On the Possibility of Life in Capitalist Ruins; and Trinh (2011) Elsewhere, Within Here: Immigration, Refugeeism and the Boundary Event.

The course readings and our other individual readings reverberate across this text and materializes our commitment to engaging in the messy work of uniting theory and practice. While we offer few, if any, citations, we offer the following quotes that we think exemplify the work we do in this piece.

"Feminism is a sensible reaction to the injustices of the world, which we might register at first through our own experiences. We might work over, mull over, these experiences; we might keep coming back to them because they do not make sense. In other words we have to make sense of what does not make sense. There is agency and life in this making" (Ahmed, 2017, p. 21).

"Creating a new vision (and version) of history requires a leap of faith" (Ramirez \& Boyd, 2012, p. 5).

"If vulnerability is a recognition that we are undone by each other, and an invitation to embrace rather than retreat from that fact, it is also a testament to how we are witnesses to moments when we are subjected to violence, particularly social structures that have been constructed to discipline and surveil" (Nash, 2019, p. 119).

"What, indeed, makes us endlessly return to the sources--those ancient, unknowable sources that keep inquiries alive and challenge every boundary set up for strategic or survival purposes? Where do we come from? Where do we go? What keeps us holding on to the thread of life, doing what we each do so earnestly in our daily existence? And what ear has suddenly caught on the whence and whither of life?" (Trinh, 2011, p. 13). 
"Th[e] invocation of intersectional movements should not leave us intact with ally models but rather create new assemblages of accountability, with ally models but rather create assemblages of accountability, conspiratorial lines of flight, and seams of affinity" (Puar, 2017, p.xxi).

"Transformation through collaboration, ugly and otherwise, is the human condition" (Tsing, 2015, p. 31).

"This is because as Indigenous people and decolonizing educators, we have responsibilities that require/urge/direct/instruct us to be good ancestors to future generations of human and non-human entities, to the earth and sky, to land and water, to the stars and the molten crevices of the earth, to the past and the future" (Tuhiwai Smith, Tuck, \& Yang, 2019, p. 23).

What we offer here is an invitation to think differently about feminisms, writing practices, and educative spaces. While collaboratively written pieces are not methodologically "new," this piece offers a unique take on these pieces. As is noted earlier in this appendix, this piece is a product of an educational space and practice. In our educational space and practice, we considered frictional unity as a site for where the work gets done. Here, we disrupt higher education practices, by writing a final paper together as a group of people immersed in such thinking. Such an uneasy union is about listening to each other and attending to how what we read, what we discussed, and so on left us with questions about our own beliefs and practices. Such a site is one of collective growth in which the instructor does not lead the class, but instead joins in the fray of frictional thought, residing in the uncomfortable spaces of that thinking, and thinks-with, becomes with students. Still, we returned to each session with an eagerness to reside in friction, to see where it promoted growth of thought. Our materialized collective presented here is full of frictions.

These frictions are about the different feminisms and rejections of feminisms that exist in our collective. We do not believe that there is a single feminism or a single feminist collaborative writing practice. We certainly do not adhere to a singular line of feminist thought in this piece. We are all much too different to shove ourselves into the oppressive box of similarity. Our feminisms, our rejections of feminisms, and our questions of feminisms pulse throughout our collective piece. These differences are the frictions, the questions we ask, the questions we must wrestle with, the questions that may not have answers. Our collaborative piece, then, materializes friction.

We frequently read our piece aloud, with each person reading their contribution, to hear the frictions. These frictions took over the space and we dissolved into the collective. We hope that sharing this article with you will do the same. We hope that this invitation to friction invades your space and dissolves you into our collective, she. We invite you to our contribution to collaborative feminist writing practices. We invite you to consider how feminists can come together in uneasy practices of solidarity with each moment of solidarity materializing both the personal and the political.

In Solidarity, 
The Collective

Corresponding Author: Susan Naomi Nordstrom,snnrdstr@memphis.edu

\section{References}

Ahmed, S. (2017). Living a feminist life. Durham, NC: Duke University Press. https://doi.org/10.1215/9780822373377-007

Aristotle, M., Buggs, WJ., Elliott, M., \& Talbert, QE. (2019). Cool Off [Recorded by Missy Elliott]. On Iconology [MP3 file]. United States: Atlantic-Goldmind Records

Batie, C., \& Decilveo, J. (2015). Rise Up [Recorded by Andra Day]. On Cheers to the Fall [MP3 file]. Los Angeles, United States: Warner Records

Boyd, N.A. \& Ramirez, H.N.R. (2012). Bodies of evidence: The practice of queer oral history. New York, NY: Oxford University Press.

Brathwaite, J., Yildirim, O., \& Martinez, R. (2017). Peace of Mind [Recorded by PartyNextDoor]. On COLOURS 2 [MP3 file]. Toronto, Ontario: OVO Sound and Warner Music Group

Brown, J., \& Ellis, A. (1968). Say It Loud- I'm Black and I'm Proud [Recorded by James Brown]. On A Soulful Christmas [MP3 file]. Cincinnati, United States: King Records

Campbell, W., Atkins, E., \& Atkins, T. (1999). Shackles (Praise You) [Recorded by MaryMary]. On Thankful [MP3 file]. New York City, United States: Columbia Records

Coffer, J., Knowles, B., Williams, CM., McIntosh, D., Duckworth, K., Tirado, F., Lomax, \& Lomax, Sr., J. (2016). Freedom [Recorded by Beyonce featuring Kendrick Lamar]. On Lemonade [MP3 file]. New York City, United States: Parkwood Entertainment

Daniel, A., \& Mejia, I. (2018). Cantu [Recorded by Amine]. On OnePointFive [MP3 file]. New York City, United States: Republic Records

Doane, J., \& Hodges, D. (1995). Writing from the trenches: Women's work and collaborative writing. Tulsa Studies in Women's Literature, 14(1), 51-57. https://doi.org/10.2307/464246

Du Bois, W. E. B. (1903). The Souls of Black Folk. New York: Dover Publications

Fox, C., \& Gimbel, N. (1996). Killing Me Softly [Recorded by Fugees]. On The Score [MP3 file]. Philadelphia; United States: Ruffhouse Records

Gordon, W., Knowles, B., Cossom, K., \& Delicata, A. (2016). Daddy Lessons [Recorded by Beyoncé]. On Lemonade [MP3 file]. New York City, United States: Parkwood Entertainment

Handforth, R., \& Taylor, C. A. (2016). Doing academic writing differently: A feminist bricolage. Gender and Education, 28(5), 627-643. https://doi.org/10.1080/09540253.2015.1115470

Harde, R. (2013). "The union of theory and practice": Using team-based learning in the feminist literary theory classroom. Feminist Teacher 22(1), 60-75. https://doi.org/10.5406/femteacher.22.1.0060

Hill, Lauryn. (2019). Guarding the Gate [Recorded by Lauryn Hill]. On Queen and Slim Soundtrack [MP3 file]. Los Angeles, United States: Motown Records

Jefferson, M., Frederic, E., Thomas, T., Sumser, S., \& Small, S. (2019). Juice [Recorded by Lizzo]. On Cuz I Love You [MP3 file]. New York, United States: Atlantic Records

Knowles, S., Cook, B., Sampha, S., Sitek, DA., Wimberly, P. (2016). Don't Touch My Hair [Recorded by Solange featuring Sampha]. On A Seat at the Table [MP3 file]. United States: Saint RecordsColumbia

Knowles, B., Dent, A., \& Knowles, M. (2000). Survivor [Recorded by Destiny's Child]. On Survivor [MP3 file]. New York City, United States: Columbia Records 
McKay, VM. (1996). The Battle is the Lord's [Recorded by Yolanda Adams]. On Save the World [MP3 file]. United States: Verity Records

Merrill, G., \& Rubicam, S. (1987). I Wanna Dance with Somebody (Who Loves Me) [Recorded by Whitney Houston]. On Whitney [MP3 file]. United States: Arista Records, Inc

Minh-ha, T. (2011). Elsewhere, within here: Immigration, refugeeism and the boundary event. New York, NY: Routledge. https://doi.org/10.4324/9780203847657

Nash, J.C. (2019). Black feminism reimagined after intersectionality. Durham, NC: Duke University Press. https://doi.org/10.1215/9781478002253-007

Rae, CB., Beck, J., Chrisanthou, S. (2006). Put Your Records On [Recorded by Corinne Bailey Rae]. On Corinne Bailey Rae [MP3 file]. Westminster, London: EMI Records Ltd.

Rasted, S., Norreen, C., Dif, R., \& Nystrom, L. (1997). Barbie Girl. [Recorded by Aqua]. On Aquarium [MP3 file]. Santa Monica, United States: Universal Music Group

Robertson, B., Robertson, E., Robertson, J. (2008). Different Breed [Recorded by Carter's Chord]. On Carter's Chord [MP3 file] Nashville, TN: Show Dog Nashville.

Rushen, P., Mims Jr., C., Franklin, K., Brown, S., \& Washington, F. (2005). Looking for You [Recorded by Kirk Franklin]. On Hero [MP3 file]. Inglewood, United States: GospoCentric Records

Simpson, IA., Ramsey, D., Sanders, S., \&Thiam, A. (2006). I Am Not My Hair. [Recorded by India. Arie]. On Testimony: Vol. 1, Life \& Relationship [MP3 file]. Los Angeles, United States: Motown Records

Simpson, IA., Saunders, S., Batson, M. (2001). Brown Skin. [Recorded by India. Arie]. On Acoustic Soul [MP3 file]. Los Angeles, United States: Motown Records

Smith, J., \& Perry, C. (2016). Something in the Way [Recorded by Jorja Smith]. On Project 11 [MP3 file]. United Kingdom: FAMM Records

Smith, L.T., Tuck, E., \& Yang, W. (2019). Indigenous and decolonizing studies in education. New York, NY: Routledge.

Tsing, A.L. (2015). The mushroom at the end of the world: On the possibility of life in capitalist ruins. Princeton, NJ: Princeton University Press. https://doi.org/10.2307/j.ctvc77bcc

Valentine, RV., Robertson, A., \& McCormick, C. (2018). Loaded Gun [Recorded by 6LACK]. On East Atlanta Love Letter [Vinyl]. Atlanta, United States: LoveRenaissance- Interscope Records

Valentine, RV., \& Yildirim, O. (2018). Cutting Ties [Recorded by 6LACK]. On Cutting Ties [MP3 file]. Atlanta, United States: LoveRenaissance- Interscope Records

Walker, A. (1983). In search of our mothers' gardens: womanist prose. San Diego: Harcourt Brace Jovanovich

Walker, S. (2019). Riot [Recorded by Summer Walker]. On Clear- EP [MP3 file]. Atlanta, United States: LoveRenaissance- Interscope Records

White, J., Knowles, B., Gordon, D., Plant, R., Page, J., Jones, JP., \& Bonham, J. (2016). Don't Hurt Yourself [Recorded by Beyoncé featuring Jack White]. On Lemonade [MP3 file]. New York City, United States: Parkwood Entertainment

Williams, P., \& Fenty, R. (2017). Lemon [Recorded by N.E.R.D and Rihanna]. On No One Ever Really Dies [MP3 file]. New York City, United States: Columbia Records

Wilson, G., Camper Jr., D., \& Love, J. (2017). Focus [Recorded by H.E.R.]. On H.E.R. [MP3 file]. United States: RCA Records

Wolinski, D. (1983). Ain't Nobody [Recorded by Rufus and Chaka Khan]. On Stompin' at the Savoy [MP3 file]. Los Angeles, United States: Warner Records

Wyatt, J., \& Gale, K. (2018). Writing to it: Creative engagements with writing practice in and with the not yet known in today's academy. International Journal of Qualitative Studies in Education, 31(2), 119-129. https://doi.org/10.1080/09518398.2017.1349957 